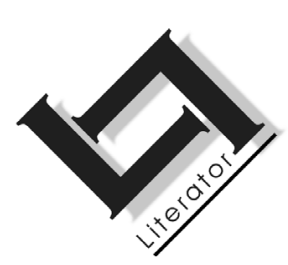

\title{
Uitbeelding van skuld en boetedoening deur die gebruik van terugkerende kodes in Die buiteveld (John Miles)
}

\author{
S. Harper \\ Departement Toegepaste Tale \\ Tshwane Universiteit van Tegnologie \\ PRETORIA \\ E-pos: harpersm@tut.ac.za
}

\begin{abstract}
Expressions of guilt and remorse through the use of recurring codes in Die buiteveld by John Miles
\end{abstract}

The novel "Die Buiteveld" by John Miles is an unusual novel. The main character is an enigma as from the start the reader has doubts about him and is in doubt of the truth. The aim of this article is to determine how recurring codes are used to express guilt and remorse. The analysis shows how suspense gradually increases through the repetitive use of certain codes. Through most of the story the reader is in doubt about the true identity of the main character and in this way further suspense is created. Guilt and admission of guilt are suggested by the repetion of different codes. The reader remains ignorant of the true identity of the main character until the end of the story. This causes suspense. Guilt and reconciliation are intensified by recurring codes. These codes are pillories, paintings by Goya, references to different wars, photos, physical scars and a knife. Through the woman Isabel the main character is guided to disclose his past gradually. As the case in the layers of the Goya portrait more and more of his past is gradually disclosed. His admission of guilt leads to the possibility of returning to his home country and of living a new life there with his beloved Isabel. The reader becomes not only a consumer but also a producer of the text. 


\section{Opsomming}

\section{Uitbeelding van skuld en boetedoening deur die gebruik van terugkerende kodes in Die buiteveld (John Miles)}

Die roman "Die buiteveld" (2003) deur John Miles is 'n vreemde roman. Die hoofkarakter is ' $n$ enigma en van die begin af wonder die leser wie hy is en wat die waarheid is. Die doel van hierdie artikel is om te bepaal hoe terugkerende kodes gebruik word om die tema van skuld en boetedoening in die roman uit te beeld. Hieruit blyk hoedat spanning geleidelik oplaai deur die herhalende gebruik van sekere kodes. Vir die grootste deel van die verhaal is die leser onbewus van die hoofkarakter se ware identiteit en dit skep spanning. Skuld en boetedoening word deur verskillende terugkerende kodes uitgebeeld. Skuldpale, Goya-skilderye, verwysings na oorlog, foto's, 'n gevaarlike knipmes en fisiese letsels kom herhaaldelik voor. Deur die vrou, Isabel, word die hoofkarakter algaande gelei tot skulderkenning en boetedoening. Soos die geval is met die lae van die Goyaportret van Isabel word geleidelik meer van sy verlede geopenbaar. Skulderkenning en boetedoening lei uiteindelik daartoe dat die hoofkarakter kan terugkeer na sy vaderland en kan uitsien na 'n nuwe lewe aldaar saam met sy geliefde Isabel. Die leser is dus nie net 'n verbruiker nie, maar ook 'n vervaardiger van die teks.

\section{1. 'n Vreemde roman}

Die buiteveld, 'n roman deur John Miles, doen met 'n eerste lees reeds vreemd aan. Die verhaal word in die derde persoon vertel en dit is onduidelik waaroor dit handel. Dit is egter wel duidelik dat daar iets geheimsinnigs aan die gang is. Daar is ook iets geheimsinnigs aan die hoofkarakter. Die leser se belangstelling word dus van die begin af geprikkel. Wat gaan hier aan? Soos die verhaal vorder, blyk dit dat die hoofkarakter, ene Smerski, 'n geheim met hom saamdra. Wie is hierdie man werklik?

Om dinge nog meer geheimsinnig te maak, is dit van die begin af duidelik dat skuld voorop staan. Aan die begin van die roman neem die hoofkarakter 'n Middeleeuse strafpaal, ook genoem skandpaal, af. Hy word deur 'n beeldskone vreemde vrou, "'n lotsgodin" wat hom "met 'n krag nader trek", daarvan beskuldig dat hy behep is met skuld en straf. Skuld en die vaslê daarvan op 'n foto word later dwarsdeur die roman aangetref. Waaraan is die hoofkarakter skuldig? Waaraan is ook ons, as lesers, aandadig en skuldig? 
Die klipsuile (padrao's) wat die Portugese seilvaarders langs die kus van Afrika geplant het toe hulle Afrika "ontdek" het, lyk baie soos die strafpale. Padrao's en skuldpale is dalk eintlik maar dieselfde, dink die hoofkarakter. Die skuld van kolonialisme is ook 'n sterk tema in die roman. Kan die kruis die leser selfs aan Christus se boetedoening aan die kruis herinner?

Die eerste paar bladsye van die boek stel die leser voor aan hierdie vreemde karakter - 'n man met die eienaardige naam, Smerski, wat lyk asof hy iemand is wat emosieloos op alles reageer. Hy is 'n enigma. Die kode van enigmas is juis een van vyf kodes in enige teks (Barthes, 1974:19).

Op die eerste bladsy met die opskrif Maandag 1, vertel iemand van 'n onrustige slaap as gevolg van gebeure die vorige dag. Daar is sprake van skuld wat die oorsaak van die slaaploosheid kan wees. Die hoofkarakter besoek 'n ou geskiedkundige pelourinho (skuldpaal) in die noordwestelike Minho-provinsie in Portugal. Die jaartal op die skuldpaal is 1652, wat die leser onmiddellik aan Jan van Riebeeck se landing aan die Kaap laat dink. Die "skuld" van die blanke in Afrika en meer spesifiek Suid-Afrika word deur die datum geïmpliseer. Die Duitse vrou, Elena, wat hy by die skandpaal leer ken, beskuldig hom dat hy met "skuld en straf" behep is (Miles, 2003:12). Sy dra kennis van 'n kommissie oor rassisme (Miles, 2003:20) in Suid-Afrika en van die "wreedhede van apartheid". Ook haar Duitse man, Willibald, gesels later saam oor "die verskriklike ellendes wat slawerny en kolonialisme oor die wêreld aangerig het" en oor "onreg" en "onderdrukking" (Miles, 2003:21).

Die leser word nuuskierig in die verhaal ingelok. In die artikel word nou gepoog om te kyk hoe die raaisel verdiep deur die gebruik van terugkerende kodes van skuld en boetedoening. Ander gesigspunte wat gebruik kan word om die roman te bekyk, sluit die uitbeelding van Portugal, die siening van Suid-Afrika ná demokrasie asook uitsprake oor taal in. Die doel van hierdie artikel is egter slegs om te bepaal hoe terugkerende kodes gebruik word om die tema van skuld en boetedoening in die roman uit te beeld.

\section{Motiewe van terugkerende kodes}

Wellek en Warren (1973:182) beweer dat sekere motiewe soos bloed en wonde dikwels herhalend in 'n werk gebruik kan word. Volgens Heilna du Plooy (Cloete, 1992:328) is die term, motief, baie nuttig, maar dit moet duidelik gedefinieer word wanneer dit gebruik word. Daar moet duidelik gestel word watter definisie in 'n spesifieke 
geval bedoel word. Die algemene omskrywing van motief is "'n element wat herhaaldelik in literêre werke voorkom" (Cloete, 1992:325). Volgens Shipley (1968:274) is 'n motief "a word or pattern of thought that recurs in a similar situation". In die formalistiese en strukturalistiese tradisie word die term anders geïnterpreteer. Boris Tomashevsky sien 'n motief as "the smallest part of a plot" (Selden \& Widdowson, 1993:34) en hy onderskei onder andere tussen "bound motif" en "free motif". In hierdie artikel verwys die term motief na die eerste definisie. ' $n$ Leitmotiv is ' $n$ bepaalde verhaalelement wat telkens in 'n bepaalde werk herhaal word sodat dit 'n besondere betekenis verkry (Cloete, 1992:325). Die Leitmotiv in die roman onder bespreking kan beskou word as skuld en aandadigheid wat deur die herhaling van verskillende motiewe uitgebeeld word.

Motief en tema word soms afwisselend vir dieselfde begrippe gebruik (Abrahams, 1981:111). Fowler (1973:195) beskryf die tema van 'n roman as "a recurrent element of subject-matter". Dit word beskou as "a branch of the subject which is indirectly expressed through the recurrence of certain events, images or symbols" (Fowler, 1973:195). Tema word deur Shipley (1968:417) beskou as "the general topic, of which the particular story is an illustration". Die tema of temas in 'n roman vorm dikwels 'n deurlopende draad. "We think of a theme as a line or thread running through a work." (Fowler, 1973:196.) Om die tema te ondersoek, moet die kritikus die werk deeglik bekyk. "Recognition of such basic themes permits fresh analysis of a work", beweer Shipley (1968:417). Nog 'n term wat hier ter sprake kan kom, is simbool. Volgens Fowler (1973:118) is dit so dat "the symbol evokes unseen worlds". Daarvolgens het simbool die funksie dat dit verwante dinge oproep. Grove (1963:87) beskou die simbool as "' $n$ teken wat 'n saak verteenwoordig". Die simbool is dus 'n voorwerp wat iets anders (gewoonlik 'n abstrakte saak) verteenwoordig (Grové, 1963:87).

Volgens Barthes is 'n kode 'n perspektief (Barthes, 1974:20) waarvolgens die literêre werk bekyk kan word. Dit is een van die stemme waaruit die werk geweef is (Barthes, 1974:20). Hiervolgens kan die terugkerende elemente in Die buiteveld beskou word as 'n kode om die werk mee te ontleed.

\section{Kode van handeling}

Robert Lindell en ander meen dat verskillende aspekte van 'n roman in ag geneem moet word wanneer dit bespreek word, sodat een aspek nie van die res geïsoleer word nie (Lindell, 1967:25). Daarom 
word baie kortliks na die verloop van die gebeure, of die kode van handeling, verwys.

Die roman is in vier dele verdeel en elkeen van hierdie dele is weer onderverdeel in ' $n$ aantal afdelings wat as dae met datums aangedui word. In deel 1 is die enigmatiese hoofkarakter, Smerski, met vakansie in die Portugese platteland waar hy twee Duitsers, Willibald en Elena, teëkom. Hulle vertoef saam by 'n herberg waar 'n kelnerin, Isabel (wat vaagweg bekend lyk en wat noem dat sy Smerski reeds voorheen ontmoet het) in Smerski se lewe inkom en selfs per ongeluk letterlik in sy bed beland. Die leser wonder wie Smerski werklik is, wie Isabel is, waar hulle mekaar voorheen ontmoet het en of hulle liefde die waarheid sal kan oorleef.

In deel 2, wat ook die langste deel van die roman is, bespiegel Isabel oor wie die enigmatiese Smerski is en oor die lewensverhaal wat Smerski aan haar vertel terwyl hulle twee saam verder deur Portugal reis. Smerski vertel dat hy as die kind van 'n Portugese vrou en onbekende pa later in Angola in die oorlog betrokke was en dat hy deur 'n vrou, die Kaptein, na Portugal gesmokkel is. Die spanning bou op as Isabel en die leser besef dat Smerski geheime het en dat hy nie die volle waarheid vertel nie. Spanning neem toe wanneer Isabel besef dat Smerski altyd 'n gevaarlike mes met hom saamdra - 'n springmes waarmee hy baie handig is. Isabel se pa, voorheen 'n minister van buitelandse sake in Portugal, is ook agterdogtig oor Smerski se agtergrond. Die spanning laai op toe Smerski en Isabel besef dat die geheimsinnige Kaptein 'n kennis van Isabel se familie is. Geleidelik vertel Smerski meer en kom die leser agter dat Smerski nie sy regte naam is nie, maar dat hy uit die Suid-Afrikaanse weermag gedros het en deur die Kaptein van 'n Portugese identiteit voorsien is. Die langste deel dek dus die leuens en bespiegelings oor wie hierdie man is. Die hoofkarakter is skuldig. Hoe gaan hy vergifnis kry?

In deel 3 is die hoofkarakter se pa, die fotograaf Jack de Villiers, tydens sy besoek aan 'n fotografie-uitstalling in Lissabon op soek na sy seun. Hy kry die beeldskone Duitse vrou, Elena, om hom te help soek. Voordat hulle egter die geheim oor wie sy seun is, kan oplos, sterf die pa in Elena se hotelkamer aan 'n hartaanval.

In deel 4 lees die hoofkarakter tydens 'n kongres in Maputo in die koerant van sy pa se dood. Met Isabel se hulp spoor hy sy stiefma op. Hy besoek plekke waar hy in sy jeug gewoon het en woon 'n gedenkdiens vir sy pa in Kaapstad by. Hy besoek ook 'n ou weermagvriend en besef dat vergifnis nie in oordrewe openbare skuld- 
erkenning lê nie. Later sluit Isabel by hom in Suid-Afrika aan en hy vertel haar dat hy saam met haar in Suid-Afrika wil woon - 'n gelukkige einde dus.

Die verhaalstruktuur, fokalisasie, milieu en tyd raak ook die uitbeelding van skuld as Leitmotiv. Die organisasie van die verhaalgegewe in hierdie John Miles-roman is nie chronologies nie en twee duidelike vertellers word onderskei. In die vier hoofdele van die roman is die verskillende vertellers afwisselend aan die woord. Deel 1 is in die derde persoon geskryf, deel 2 in die eerste persoon (in die persoon van Isabel), terwyl dele 3 en 4 weer in die derde persoon vertel word. Deel 2 is die langste deel met 151 bladsye teenoor die 36 bladsye van deel 1, die slegs 20 bladsye van deel 3 en die 43 bladsye van die laaste deel. Dit laat die vermoede ontstaan dat die belangrikste tema in die tweede deel behandel of bespreek word deur die uitgebreide plek wat daaraan afgestaan word. Die aantal afdelings kan ook ' $n$ aanduiding wees. Deel 1 het drie onderafdelings, deel 2 tien, deel 3 slegs twee en deel 4 drie dele. Hierdie feit gee reeds ' $n$ aanduiding dat sekere afdelings belangriker as ander kan wees. In die tweede en langste deel bespiegel Isabel oor Smerski se ware identiteit en beskryf sy sy skuldgevoelens. Dit versterk die vermoede dat die hantering van Smerski se skuld die belangrikste tema kan wees.

Die milieu van die verskillende dele verskil ook. Dele 1 en 2 het die platteland van Portugal as agtergrond terwyl deel 3 in Lissabon (Portugal) afspeel. Deel 4 speel in drie stede in suidelike Afrika af, naamlik in Maputo, Johannesburg en Kaapstad. Die grootste deel van die verhaal speel egter in Portugal af. Teen die einde van die verhaal is die milieu suidelike Afrika en val die aandag op SuidAfrika en die Suid-Afrikaanse problematiek. Gebeurtenisse wat in die Portugese geskiedenis geïdentifiseer is, word in die laaste deel op die Suid-Afrikaanse situasie van toepassing gemaak. Teen die einde sluit die roman in Suid-Afrika af.

'n Duidelike tydperk in die Suid-Afrikaanse geskiedenis word gedek, naamlik vanaf die tyd van die grensoorlog tot 2003 met die verskyning van die roman. Die verhaal strek ook oor die hoofkarakter se lewe tot by sy huidige situasie aan die einde van die roman. Die verhaal word binne 21 dae vertel, maar met terugflitse wat die hoofkarakters se hele lewensloop dek tot en met die gelukkige einde, of die oplossing.

Die buitelyn van die roman volg wel 'n chronologiese tydsverloop. Die datums wat in die indeling en by elke onderafdeling aangedui 
word, strek oor slegs 21 dae - vanaf Maandag die 1e tot en met Sondag die 21e. Sekere hoofdele en onderafdelings oorvleuel. Die laaste dag van deel 1 is byvoorbeeld weer in deel 2 se eerste onderafdeling aanwesig. Deel 1 strek oor drie dae, deel 2 oor tien dae, deel 3 oor twee dae en die laaste deel oor vier dae. Dit versterk ook die moontlikheid dat die tweede deel waarin die hoofkarakter se gevoelens bekyk word, die belangrikste deel mag wees. Tekstyd en storietyd (Rimmon-Kennan, 1983:45) is, soos dikwels die geval in romans is, ook hier nie dieselfde nie. Geen maand of jaartal word in die inhoudsopgawe aangedui nie. Die verhaal kan dus gedurende enige jaar afspeel. Dit kan daarop dui dat dit meer universeel-geldig is.

\section{Skuld}

Wanneer sy pa in Elena se hotelkamer sterf, besef die hoofkarakter dat dit eintlik hy is wat moes gesterf het (Miles, 2003:229). Hy is die skuldige wat gestraf behoort te word. Die hoofkarakter het, soos die leser later agterkom, in die Suid-Afrikaanse grensoorlog geveg en gedros. Hy het baie skuldgevoelens oor sy deelname aan die oorlog. Skuld het reeds in vorige romans van Miles voorgekom. Volgens Pakendorf (2003:15) was die skrywer vroeër baie "teen burokrasie en magsmisbruik" gekant, soos dit blyk in 'n vorige roman, Kroniek uit die doofpot, wat 'n "welsprekende aanklag teen geweld, korrupsie en toesmeerdery in die ou Suid-Afrika" (Pakendorf, 2003: 15) was. Ook Burger (2003:16) verwys daarna dat Kroniek uit die doofpot "'n soort dokumentêre roman oor magsvergrype" was. In Die buiteveld meen die hoofkarakter dat beheer deesdae veel subtieler is as in vorige tye (Miles, 2003:18). Jack, die hoofkarakter se pa, sê dat kolonialisme ' $n$ minderheid "op een of ander wyse die mag [laat] inpalm om duisende onderdane arm te hou" (Miles, 2003:216). Ook oor kolonialisme is daar skuldgevoelens.

Vervolgens kan gekyk word na die manier waarop die skuld uitgebeeld en beklemtoon word.

\section{Die nut van herhalende kodes}

Die tema van skuld en boetedoening word sterk beklemtoon deur die herhaling van sekere terugkerende motiewe of kodes. Die herhalende gebruik van dinge soos skuldpale, 'n gevaarlike mes, skilderye, kameras en die vaslê van gebeure op foto's beklemtoon die skuld. 
Die tweede deel waarin die hoofkarakter die leuen oor Smerski se kinderdae, sy oorlogsdae en daarna aan Isabel vertel, behels die grootste deel van die roman. Hierdie feit het reeds die vermoede laat ontstaan dat skuld en belydenis 'n kernmotief kan wees. In hierdie deel wat deur Isabel en nie die hoofkarakter, Smerski, vertel word nie, bespiegel die meisie hoofsaaklik oor Smerski se emosies en gevoelens. Sy optrede en emosies dui vir haar op sy skuld en aandadigheid. Die skuldmotief bind die werk tot 'n eenheid, "it causes us to see the book as a whole" (Forster, 1927:138).

Saam met die skuldtema hoort ook die tema van boetedoening en versoening. Burger (2003:16) wys daarop dat 'n vorige roman van Miles "'n skrikwekkende perspektief op die gevolge van strukturele geweld, op skuld en aandadigheid" gebied het. Burger (2003:16) meen dat "die idees van skuld en identiteit ondersoek" kan word. Behalwe sy oorlogskuld is Smerski ook daaraan skuldig dat hy op meer as een geleentheid dieselfde vrou as sy vader begeer het. Smerski en Carlos oorweeg 'n aanhaling uit die ou Griekse dramaturg, Sophokles, se Koning Oedipus as motto vir hulle bloemlesing van vertaalde gedigte van Breyten Breytenbach se bannelingpoësie (Miles, 2003:186). Die motto wys op skuld en boetedoening daaroor. Hulle oorweeg Oedipus se vraag: "Hoe sal versoening geskied?" en Kreon se antwoord: "Deur ballingskap. Of boetedoening deur bloed vir bloed" (Miles, 2003:186). Die hoofkarakter moet vrygespreek word van al sy skuld, maar hoe?

Die herhalende motiewe is hoofsaaklik skuldpale, littekens (wat ewigdurende aandadigheid simboliseer), 'n gevaarlike mes, verwysings na oorloë, Goya-skilderye, 'n kamera, foto's en verwysings na die buiteveld waarin die hoofkarakter lank vertoef het.

\section{Skuldpale}

Soos reeds genoem, is op die tweede bladsy al sprake van 'n ou geskiedkundige pelourinho (skuldpaal) met die jaartal 1652. Dit herinner die leser dadelik aan Jan van Riebeeck se landing aan die Kaap. Die beeldskone Elena beskuldig die hoofkarakter dat hy met "skuld en straf" behep is (Miles, 2003:12). Sy dra kennis van die "wreedhede van apartheid". Ook Willibald verwys na "die verskriklike ellendes wat slawerny en kolonialisme oor die wêreld aangerig het" en oor "onreg" en "onderdrukking" (Miles, 2003:21).

Smerski sien later (Miles, 2003:25) ook 'n kafeetjie wat Pelourinho heet, na die strafpaal. Die latere ruwe suil van 'n menhir of staanklip herinner hom ook weer aan die klipsuile of padrao's wat die Portu- 
gese seilvaarders langs die kus van Afrika geplant het (Miles, 2003:30). Hy dink dat die padrao's maklik met strafpale verwar kan word en dat padrao's en skuldpale dalk eintlik maar dieselfde is. Die kruise wat deur die vroegste seevaarders geplant is, word gelykgestel aan skuld, waarskynlik die skuld van kolonialisasie. Wanneer Elena (Miles, 2003:44) Smerski beskuldig dat hy 'n man is wat geen skuldgevoelens het nie en dus geen boetedoening hoef te doen nie, verduidelik hy dat die geëmansipeerde mens alles met hom saamdra, "die skuld en die verontskuldiging". Hy meen verder dat die mens vir skuld en boetedoening op homself aangewese is (Miles, 2003:45). Verdere herhaling beklemtoon ook die idee van skuld en aandadigheid. Smerski neem later (Miles, 2003:91) nog 'n pelourinho in 'n klein Portugese dorpie af om vir sy vriend wat Portugese skandpale skilder, te wys. In die volgende dorpie besoek hulle ook 'n goeie voorbeeld van 'n ou Gotiese skandpaal; hierdie keer op die rug van die beeld van 'n prehistoriese bosvark (Miles, 2003:92). Die vele skuldpale versterk die deurlopende idee van skuld. Hoe gaan die hoofkarakter van al hierdie skud ontslae raak?

\section{Goya-skilderye}

Een van die sterkste herhalende elemente in die roman is die Goyaskilderye. Aanvanklik lyk dit asof hierdie skilderye nie mooi in die skuldraamwerk inpas nie. Goya se portretstudies is baie bekend die heel bekendste is seker die besondere portretstudie van Dona Isabel de Porcel. Goya het aan die begin van sy loopbaan portretstudies van adellikes om den brode geskilder (Carr-Gomm, 2005: 15). In 'n tyd voor kameras bestaan het, was die skilder van vooraanstaande, ryk individue en familiegroepe 'n lonende bedryf. Skilderye van mense is later, soos die tegnologie gevorder het, deur die moderner weergawe van kameras wat foto's neem, vervang. Goya se latere lewe is oorheers deur gedagtes oor die gruwelikhede van oorlog. Hy is dus naas sy skilderye van adellikes ook veral bekend vir sy latere skilderye wat die aaklighede van oorlog uitbeeld. Hierin sluit Goya se skilderye by die gruwelikhede van oorlog en die gepaardgaande skuldtema aan.

\section{1 'n Koninklike familieportret}

'n Bekende Goya-skildery is dié van Karel IV en sy gesin. In Isabel se woonplek haal die hoofkarakter 'n boek oor Goya uit die boekrak en kyk na die skildery wat Goya van Karel IV en sy gesin gemaak het. Isabel het reeds as kind besef dat haar ouma se oorbelletjies (Miles, 2003:76) baie lyk soos die oorbelletjies van die klein Dona Maria Isabel op die Goya-skildery. Daar word dus 'n verdere oor- 
eenkoms tussen die vroulike hoofkarakter en die Goya-skildery getrek. Die koninklike gesin herinner Isabel ook aan die gesin van haar vorige man (Miles, 2003:145). Selfs die name kom ooreen. Die koninklikes in Goya se tyd wou graag hulle adellikheid ten toon gestel het, maar Goya het hulle met verbasende eerlikheid en in hulle menslike swakhede geskilder (Howard, 2003:36). Hy het hulle laat lyk soos gewone mense; soos die gesin van die bakker op die hoek wat so pas die lotery gewen het (Howard, 2003:36). So word hulle aan gewone mense met foute gelykgestel.

\subsection{Portretstudie van Donna Isabel}

Die mees pertinente Goya-skildery in die roman is die bekende portretstudie van Donna Isabel Cobos de Porcel wat as die mees majestueuse van Goya se portrette beskou word (Howard, 2003:40). Die buiteblad van die roman toon 'n man se agterkop met daaragter 'n vae beeld van hierdie skildery, getitel Dona Isabel de Porcel deur Goya, die bekende Spaanse skilder. Hierdie olieverfskildery $(82 \mathrm{~cm}$ by $54 \mathrm{~cm}$ ) dateer uit 1804 en is geskilder in 'n tyd van groot politieke onrus en bloedvergieting. Dit hang tans in die National Gallery in Londen. Donna Isabel de Porcel was die vrou van een van Goya se grootste vriende, Antonio Porcel (Carr-Gomm, 2005:35). 'n Groot deel van die skildery se bekoring is die kontras tussen swart en goud (Carr-Gomm, 2005:36). 'n Swart kantmantilla hang van Donna Isabel se kop oor haar skouers en beklemtoon die ligte vel en effe uitdagende houding. Sy dra die klere van 'n maja wat destyds mode was onder die elite (Carr-Gomm, 2005:35). Die maja-kleredrag dra die suggestie van uitdagende seksualiteit (Howard, 2003:40). Die oordadige dik grimering dra hierdie idee verder uit (Howard, 2003: 45). Dui die gebruik van die maja-kleredrag dalk ook op die skuld van die hooffiguur, want hy dra ook seksuele skuld? Die verdere geskiedenis van hierdie Goya-skildery is ook baie interessant. Daar is later bevind dat Goya die vrouefiguur bo-oor dié van 'n man, wat effens onder die vrou staan, geskilder het (Howard, 2003:43). Dit kan dalk daarop dui dat die man deur die vrou uitgebeeld word, soos onder andere in die lang gedeelte waar Isabel oor Smerski en sy skuld bespiegel.

Op die voorblad van die Miles-roman kom ook die agterkop van 'n man onder die uitbeelding van die meisie voor. Dit kan ook die oorheersend mag van die vrou op die man versinnebeeld. Die mag van die vrou oor die man kom duidelik in Miles se roman na vore. Smerski word deur verskeie vroue betower en sy pa sterf in die arms van een van dié vroue. Wanneer die buiteblad noukeurig be- 
kyk word, sien 'n mens dat die vrou se hand op die skouer van die manlike figuur op die voorgrond rus - dus die manlike figuur vashou.

Wanneer die hoofkarakter, Smerski, in 'n herberg in Portugal op sy Duitse vriende, Willibald en Elena, wag, kom hy agter dat die kelnerin by die dienstoonbank hom in die oog hou. Hy besef dat daar iets bekends aan haar is, maar hy kan haar nie aanvanklik plaas nie. Sy tree met hierdie ontmoeting op asof sy hom ken (Miles, 2003:37). Smerski sê aan die meisie dat hy haar herken, want "Goya het jou geskilder" (Miles, 2003:42). Behalwe vir die ooglopende vleiery en toenadering wat hierdie woorde op die eerste vlak is, word sy hier reeds gelykgestel aan die figuur in die skildery. Sy antwoord dat sy nie gedink het hy sou onthou dat sy voorheen die Spaanse skilderkuns van die tyd van Goya bestudeer het nie, want "ons het mekaar maar een keer ontmoet" (Miles, 2003:42). Die spanning laai nou by die leser op, want die aanduiding is dat hulle mekaar reeds ontmoet het. Benewens dat sy soos die Goya-meisie lyk, is sy ook 'n kenner van Goya se kuns.

Die ooreenkomste tussen Isabel en die figuur in die Goya-skildery word al hoe meer. Die kelnerin met die kastaiingbruin hare lyk vir Smerski presies soos die maja in die bekende Goya-skildery. Haar bruin hare herinner hom verder aan die kastaiingbome buite die herberg. "Ligbruin hare, kastaiingbruin. Om by die oë te pas. En by die vrugte van die bome hier buite" (Miles, 2003:36). Die meisie in die skildery word na die huidige situasie getransformeer. Die belangrike vrouekarakter in die roman word geleidelik die vrou in die skildery. Die naam van die vroulike hoofkarakter blyk selfs dieselfde as die meisie in die skildery te wees, naamlik Isabel. Die vroulike hoofkarakter word aan die meisie in die skildery gelykgestel en word een met haar. Nie net het die lewende meisie dieselfde naam as die meisie in die portret nie, maar sy lyk ook sprekend op haar naamgenoot. Sy word die meisie in die bekende Goya-skildery.

Die verhaal verloop verder wanneer die vet en vatterige herbergier, Manny, by die kelnerin aanlê. Wanneer sy in die nag van hom wegvlug, vlug sy na Smerski se karavaan. Smerski noem Isabel soms Isabel Lobos de Portel (Miles, 2003:64) - na die volle naam van die edelmeisie in die skildery. Hy beweer dat hy Isabel nie aan die dame in die skildery meet nie, maar die dame in die skildery aan haar, Isabel, meet. So word die twee vervleg.

Isabel speel enersyds die rol van die sensuele verleidster, maar sy word algaande ook sy gids wat hom lei om meer omtrent homself openbaar te maak. Sy lei hom geleidelik tot konfessie en uiteindelik 
tot geluk. Soos wanneer die verskillende lae van die Goya-skildery afgeskraap word en 'n mansfiguur onder die oppervlak vertoon, so word Smerski afgestroop totdat daar by die ware Smerski uitgekom word.

\subsection{Goya-selfportret}

'n Ander Goya-skildery waarna verwys word, is 'n Goya-selfportret. In Smerski se kamer in Coimbra sien Isabel 'n mooi geraamde ets van 'n selfportret van Goya (Miles, 2003:185). Omdat die selfportret in die persoonlike ruimte van Smerski se kamer hang, dui dit daarop dat Smerski homself met Goya vereenselwig. Die skildery kan selfs as 'n soort foto van die hoofkarakter gesien word. Dit mag daarop dui dat Smerski homself as Goya sien, met hom identifiseer en hom met Goya se standpunte oor geweld en oorlog vereenselwig. Goya het homself teen die einde van sy lewe die wreedhede van oorlog erg aangetrek en daarop in sy skilderye gefokus.

\subsection{Goya se skilderye oor oorlog}

Goya se latere skilderye beeld duidelik die wreedhede en futiliteit van oorlog uit. Toe Smerski Isabel in die kroeg raaksien (Miles, 2003:54), kom die leser agter dat Isabel vroeër die Spaanse kunsgeskiedenis in die tyd van Goya bestudeer het. Daar word juis verwys na 'n tentoonstelling van Goya se latere skilderye Caprichos en die Gruwels van oorlog. In hierdie skilderye word die wandade van die oorlog belig. Smerski noem dat dit jammer is dat hy en hulle geselskap die gruweldade nie so goed soos Goya kan oorvertel nie. Isabel meen Goya se latere werk is sy beste werk. In hierdie skilderye het Goya sosiale kommentaar gelewer deur die aaklighede van oorlog en die aandadigheid aan gruweldade uit te beeld. Die skrywer lewer ook kritiek op oorlog en voel medeverantwoordelik en skuldig aangesien hy aan die Suid-Afrikaanse bosoorlog deelgeneem het. Dit kom aan die lig dat nog ' $n$ vrouekarakter in die roman Goya bewonder. In Isabel se e-pos aan Smerski noem sy dat die hoofkarakter se stiefma, die vrou van Jack, ook 'n skilder is wat van Goya hou. Isabel wonder waarom Suid-Afrikaners 'n voorliefde vir Goya het (Miles, 2003:240). Dit kan wees omdat Suid-Afrikaners ook skuldig voel oor oorlog. Hierdie verwysing verbind die oorlogtema verder aan Suid-Afrikaners. In die laaste verwysing na Goya in die roman dink Smerski aan Goya se latere reeks etse wat die sinloosheid en dwaasheid van oorlog uitbeeld (Miles, 2003:267). Soos Goya wil Miles ook op die sinloosheid van oorlog wys. Die herhaaldelike verwysings na Goya se skilderye beklemtoon telkens skuld en aandadigheid aan die wreedhede van oorlog. 


\section{Foto's}

Waar dinge in Goya se tyd deur die skilder se kwas vasgelê is, dien die kamera tans dieselfde doel. Daar is baie verwysings na foto's. Kameras word gebruik om aandadigheid aan skuld vas te lê. Smerski se skuld word verewig deur 'n kamera wat foto's van sy dade neem. Die leitmotief van skuld bly die leser so by.

Smerski se eie bedrewenheid met 'n kamera en die goeie kwaliteit van sy kamera val Isabel ook van die begin af op (Miles, 2003:195). Aan die begin van die verhaal is dit deur die kamera wat die hoofkarakter Elena ontmoet en kort daarna ook haar man, Willibald (Miles, 2003:12). Die hoofkarakter neem aan die begin foto's van 'n pelourinho. Hy neem eintlik bewyse van skuld en boetedoening af. Maar hy neem ook Elena saam met die skuldpaal af. Elena het later 'n verhouding met Jack. Die feit dat sy saam met die skuldpaal afgeneem word, dui op haar skuld. Elena vra: "Is jy nie bang vir wat jou foto's sê nie?" (Miles, 2003:16) en dit is juis dat hy met skuld, soos verteenwoordig deur die skuldpale, vereenselwig word.

Ook ander kameras en fotograwe kom ter sprake. Op die lughawe waar Isabel Smerski by sy vertrek na 'n kongres in Angola afsien, hang daar 'n stilte tussen hulle totdat Smerski aan Isabel sê: "Daardie fotograaf het jou ontstel" (Miles, 2003:191). Eers 'n paar bladsye later leer ons meer omtrent die voorval. Omdat Smerski in die geselskap van die gewese vrou van sy hoof by die woordeboek is en ook omdat Smerski moontlik gesoek word, word hulle ontsenu toe 'n onbekende fotograaf hulle op die lughawe afneem - veral omdat die foto geneem word toe Isabel struikel en hy haar probeer help (Miles, 2003:194), want dit mag moontlik op intimiteit dui. Die kamera neem hulle geheime saamwees af. In sy toespraak tydens die tentoonstelling van foto's in Lissabon sê die burgemeester: "fotografie is 'n wonderlike medium, visueel en wonderbaarlik direk" (Miles, 2003: 217).

Jack de Villiers is 'n fotograaf van beroep. Smerski vertel per e-pos aan Isabel dat hy as kind tussen kameras grootgeword het (Miles, 2003:232). Toe hy op laerskool was, het sy pa as fotograaf by 'n koerant gewerk en hy het altyd kameras gehad wat om hom gehang het. In die verhaal is Jack juis op pad na 'n fototentoonstelling en 'n fotografieslypskool in Lissabon. Jack en sy vriend, Elvin, word op die Lissabonlughawe gesien met "kamerasakke ongeërg oor die skouer" (Miles, 2003:205). Luis, 'n gemeenskaplike vriend van Smerski se pa, Jack, en Elena von Eschwege, was ook "nooit sonder sy kamera nie" (Miles, 2003:208). Almal lê dus gedurig gebeure vas. 
Jack neem 'n foto van Elena teen die agtergrond van 'n muurskildery van 'n soldaat (Miles, 2003:211). Hulle het na hierdie muurskildery gaan soek, omdat Jack deur 'n brief sy vermiste seun met hierdie skildery verbind het (Miles, 2003:207). Dit was die muur waarop Smerski uitgekyk het. Hulle wys 'n foto van Jack se seun aan die hospita en so word hy herken as die man wat lank gelede saam met die poskantoorwerker daar gewoon het (Miles, 2003:214). Deur ' $n$ muurskildery en 'n foto vind hulle Smerski se spoor. Jack lê ook self sy skuld op foto's vas, want 'n prominente foto deur Jack op die tentoonstelling toon 'n meisie met 'n kaal bolyf op 'n motorfiets (Miles, 2003:217). Die meisie op die foto lyk baie na Elena (Miles, 2003:218). So word die verbintenis tussen Jack en Elena openbaar. $\mathrm{Na}$ Jack se dood laat sy weduwee 'n boodskap dat Smerski na Jack se kameras moet kom kyk. Daarin vind hy digitale materiaal van 'n foto van Elena voor die muurskildery in Lissabon, wat hom laat besef dat sy pa en Elena na hom gesoek het. Foto's lê gebeure vas en deur foto's word skuldiges dus uitgewys. Die herhaalde verwysings na foto's en kameras wys daarop dat skuld vasgelê en verewig word en dus nie ontken kan word nie.

\section{Oorloë}

Verwysings na oorloë behels die Suid-Afrikaanse grensoorlog, Portugese oorloë en Goya se skilderye oor die wreedheid en nutteloosheid van oorloë. Die Suid-Afrikaanse bosoorlog waaraan hy deelgeneem het, veroorsaak skuldgevoelens by die hoofkarakter. Smerski vertel aan Isabel van sy en sy medesoldate se skuldgevoelens tydens hulle militêre diensplig (Miles, 2003:188). Hulle was drie vriende, naamlik Smerski, 'n teologiese student en 'n plantkundige. Hulle is al drie erg deur die wreedhede van die grensoorlog getraumatiseer - soveel so dat Albie, die plantkundige, selfmoord gepleeg het. Vir die plantkundige was die "wonde" wat die oorlog aan die veld aangerig het verder ook vernietigend (Miles, 2003:190). Smerski vertel dat hy daarna uit die Suid-Afrikaanse weermag gedros het. Benewens die Suid-Afrikaanse grensoorlog word daar ook na Portugese oorloë verwys. Smerski se wedervarings in die grensoorlog laat Isabel aan Portugese oorloë dink (Miles, 2003:190). Alle oorloë word eintlik in die roman veroordeel. Die idee van oorlog en die gruweldade van oorlog sluit baie nóu aan by die verwysings na die Goya-skilderye. Teen die einde van Goya se lewe het hy die wreedheid en sinloosheid van oorlog uitgebeeld. Daar is reeds vroeër verwys na die verskillende skilderye wat die wreedheid en sinloosheid van oorlog uitbeeld. 


\section{Littekens}

Skuld en aandadigheid merk die skuldige soos 'n litteken waarvan hy nie kan ontkom nie. Volgens Pakendorf (2003:15) dra Smerski "die letsels op sy rug en kuit" met hom saam soos 'n las. Die herinnering aan sy aandadigheid dra hy die hele tyd soos 'n onuitwisbare letsel met hom saam en hy kan nooit daarvan ontslae raak nie. Die verwysings na die litteken op Smerski se rug dui ook op die hoofkarakter se geheimsinnige verlede en help om spanning te skep. Terwyl hulle in Chaves is, sien Isabel die litteken as "'n dun slootjie in sy vel wat gaandeweg dieper indring op pad na die skouer waar dit wegraak" (Miles, 2003:82). Hy beweer dit is van 'n skietongeluk "lank terug" (Miles, 2003:82). Later sien sy ook 'n letsel aan sy kuit (Miles, 2003:83): "Asof die een of ander wilde dier 'n hap uit sy been geskeur het". Die sien van die aaklige littekens aan Smerski dui op Smerski se aandeel in geweld en dit laat Isabel en die leser verder oor die hoofkarakter se verlede wonder. Dit laat ook die spanning in die roman oplaai. Die fisiese tekens kan vir die leser ook op geestelike letsels dui, want Smerski en diegene wat hom beter leer ken, bly die hele tyd van sy skuld bewus, van sy aandeel in ongeregtigheid.

\section{Mes}

Smerski se geheimsinnige verlede word ook bevestig deur die mes wat hy altyd saam met hom dra om homself te kan verdedig. Miles het self in 'n gesprek met Roos (2004:151) gesê, Smerski "word aan sy mes geken". Smerski is baie behendig met sy knipmes soos blyk uit die gemak waarmee hy die handvatsel van sy tweedehandse motortjie herstel (Miles, 2003:76). Ook die meganisme van die motortjie se reënveërs word met die mes reggestel (Miles, 2003:78). Isabel dink: "Wat hy nie alles met daardie mes kan uitrig nie!" (Miles, 2003:78). Die element van die mes word herhaal in die verwysing na 'n mes in die novelle Isabella waarvan Smerski Isabel vertel het (Miles, 2003:88). Die verteller in die novelle wil sy geliefde se naam, Isabelle, uitkrap en toe die hout meegee, val hy die hout met die mes aan (Miles, 2003:88). Dieselfde vrouenaam word herhaal terwyl die onbeheerstheid van die karakter en die gevaarlikheid van die mes beklemtoon word.

Isabel ontdek die knipmes wanneer dit per ongeluk uit Smerski se baadjiesak val (Miles, 2003:93). Sy wonder of sy haar aan iemand kan verkleef wat so 'n "springmes" met hom saamdra (Miles, 2003: 96). Sy wonder ook of hy die mes voor of ná sy wonde gekry het. Het hy homself met die mes verdedig, maar is ten spyte daarvan 
gewond of het hy die mes ná die tyd bekom om homself in 'n soortgelyke situasie te beskerm? Die mes het 'n stewige hef en die lem het 'n effense kromming (Miles, 2003:93). Isabel wonder wat 'n woordeboekman soos Smerski met so 'n gevaarlike mes maak - 'n mes "met 'n krom lem wat spitspunt begin en geleidelik breër word soos die enkelblaar van 'n lotus" (Miles, 2003:93). Alhoewel die mes as mooi soos 'n blom aangedui word, lyk dit soos 'n sekel. Die sekel kan dalk op die simbool van die Kommunisme dui, maar wys in elk geval op gevaar. Die gedagte aan die mes bly Isabel pla (Miles, 2003:97). Wanneer Isabel voor Smerski op 'n smal voetpaadjie loop, wil sy 'n grap maak oor die mes (Miles, 2003:101), maar doen dit tog nie. Isabel wonder dikwels oor die mes wat sy per toeval ontdek het: "Dit was 'n springmes, 'n uitskietmes, geen onskuldige snoeimes nie, die lem veel korter as die ronde metaalhef; geen mes vir alledaagse gebruik nie" (Miles, 2003:94).

Deur herhaalde verwysing na die gevaarlike wapen word dit 'n onheilspellende refrein en hierdeur neem die spanning toe. Wanneer ' $n$ jong man een aand in 'n Portugese herberg onbehoorlike aandag aan Isabel gee en Smerski opspring om haar te beskerm, het sy haar verbeel dat daar "iets", waarskynlik die mes, in sy regterhand was (Miles, 2003:111). Sy het besef dat hy die mes sal gebruik "nog vinniger as wat jy by die woord kan kom" (Miles, 2003:111). Toe het sy ook besef dat hy al 'n mens met daardie mes doodgemaak het. Smerski begin daarna om haar van sy verlede te vertel. Hy het die mes by 'n verkoolde lyk in Angola gevind. Hy vertel ook hoe hy die meisie wat hy "die Kaptein" noem, se lewe gered het deur die mes te gebruik (Miles, 2003:133). Nadat hy die verhaal aan Isabel vertel het, soebat sy Smerski om die mes aan haar te gee (Miles, 2003:135), maar hy maak 'n grap daaroor dat dit dan soos met Simson sal gaan (Miles, 2003:135). Hy bedoel dus dat hy sy sterkte sal verloor as sy die mes van hom afneem - soos Simson se hare, versimboliseer Smerski se mes sy manlikheid en krag.

Wanneer Smerski Isabel se ouers ontmoet, wonder Isabel wat hy met die mes gedoen het (Miles, 2003:151). Ook later wanneer die hoofkarakter sy ware geskiedenis aan haar begin vertel, dink sy aan die mes (Miles, 2003:172). Sy beskuldig hom: "Jy het meer mense bygedam met daardie mes!" (Miles, 2003:172). Ook wanneer Isabel hom op die lughawe afsien voor hy na 'n kongres in Angola vertrek, wonder sy of hy die mes steeds by hom het. Sy sien die mes as "sy paspoort tot Portugal" en wonder of hy ooit daarsonder reis (Miles, 2003:192). Deur herhaalde gebruik word die mes simbool van aan- 
dadigheid aan skuld, omdat hy dalk iemand vermoor het. Dit skep spanning.

\section{Grens en buiteveld}

Die verwysings na die Suid-Afrikaanse grens en destydse grenssituasie kan die roman tot die "grensliteratuur" laat behoort. Smerski voel skuldig dat hy aandadig was aan die oorlog op die grens. Hy voel so skuldig dat hy by die eerste vertel van sy wedervarings die feite verander om sy skuld te verbloem. Eers later in die verhaal kom die leser agter wie Smerski werklik is en hoedanig hy aan die grensoorlog deelgeneem het. Ook die hoofkarakter se medesoldate het skuldgevoelens. Sy twee vriende hanteer die skuld op verskillende maniere. Die een pleeg selfmoord en die ander probeer homself verontskuldig deur oordrewe boetedoening. Die woord grens dui egter op meer as net die fisiese oorlogsgrens. Die idee van die "grens" is in hierdie roman tot 'n groot mate sinoniem met "buiteveld". Volgens Venter (2003:11) vorm die "buiteveld-posisie" die idee van Miles se roman. Venter haal die volgende uit Miles se roman, Donderdag of Woensdag, aan: "'n vae vrees: hoe lyk dit buite? Buite alles." (Venter, 2003:11). Miles self het beweer dat "die buiteveld" eintlik 'n geestelike ruimte is waarin die hoofkarakter altyd verkeer (Roos, 2004:149). Dit is moontlik waarom Isabel aan die einde van die roman beweer dat Smerski eintlik nog altyd daar (in die buiteveld) was. Volgens Miles self het hy ook die sportverwysing in gedagte gehou. In krieket is die speler in die buiteveld 'n baie belangrike veldwerker wat "op die rand staan" (Roos, 2004:149). Die gholf-sportterm is ook deur Miles in gedagte gehou (Roos, 2004: 149). Die persoon in die buiteveld, soos die hoofkarakter hier, is dus 'n belangrike persoon wat dinge moontlik ook meer objektief kan beskou en kommentaar lewer. Die titel, Die buiteveld, kom vir die eerste keer voor tydens Isabel se verjaarsdag waar Smerski haar 'n spesiale verjaardagete belowe vir haar "verjaarsdag in die hart van die buiteveld" (Miles, 2003:109). Hulle was in 'n klein dorpie in die Portugese platteland. Dit lyk hieruit asof "die buiteveld" na die buiteland en veral Portugal verwys waar Smerski vir 'n lang tyd woon. Teen die einde van die verhaal besluit Smerski om ná die kongres in Maputo na Suid-Afrika te gaan vir sy pa se begrafnis, en dink dan dat hy van die "buiteveld" af teruggebring word "werf toe" (Miles, 2003:235). Daaruit blyk dit dat hy die buiteland waar hy in ballingskap is, sien as die buiteveld en Suid-Afrika as tuis. Die idee van ' $n$ buiteveld word verder deur Roos (2004:138) benadruk. Roos (2004: 149) meen dat die slotwoorde impliseer dat hy altyd op reis is en nooit finaal tuiskom nie. Smerski sê teen die einde van die roman 
aan Isabel dat hy eendag wil terugkom na die "buiteveld" (met 'n kleinletter). Isabel antwoord dat hy lank reeds daar is (in die Buiteveld, met 'n hoofletter) (Miles, 2003:268). Dit dui eerstens daarop dat die hoofkarakter lank in die buiteveld was (terwyl hy in Angola en Europa was). In die buiteveld kon hy as buitestander meer objektief waarneem. Teen die einde van die verhaal is hy uiteindelik tuis. In die buiteveld het die hoofkarakter die hele tyd onder skuld gebuk gegaan. Sal hy noudat hy terug is, van sy skuld ontslae wees?

\section{Boetedoening}

Wanneer Smerski en Isabel na 'n foto van 'n pelourinho by Braganca kyk (Miles, 2003:167), sê Smerski wanneer 'n mens bieg, jy eintlik steeds by 'n skandpaal staan, "want versoening is geen ooreenkoms tussen gelykes nie. Versoening geskied by wat die sterkste party goedkeur en aanvaar" (Miles, 2003:197). Bieg in die politiek kan volgens Jack egter ook "maklik ingespan word om jou verder te verneder of te elimineer" (Miles, 2003:220). Oordrewe bieg word gekritiseer. Roos wys daarop dat die hoofkarakter meen "die ewige gebieg en jammerlike belydenis is vir die swakkeling" (2004: 149). Die hoofkarakter besef dat selfbejammering die sekerste manier is om jou vryheid prys te gee (Miles, 2003:230). Die hoofkarakter besef dat skuldgevoelens ' $n$ mens se lewe kan verander, want "skuldgevoel kap jou bene én arms af" (Miles, 2003:230).

Smerski lees tydens die kongres in Maputo in 'n ou aantekeningboekie oor Satre se Vlieë. Orestes het na sy plek van herkoms teruggekeer en gevind dat die gemeenskap in berou en boetedoening vasgevang was. Die inwoners herinner mekaar gedurig aan hulle skuld en is vol wroeging en behep met die verlede (Miles, 2003:235). Smerski beweer "openbare belydenis is die nasionale tydverdryf". Hierdie voortdurende skuldbesef en belydenis lei tot onvryheid en doodsheid (Miles, 2003:235). Teen die einde van die roman sê Smerski "openbare belydenisse is vir my die ergste vorm van selfbejammering" (Miles, 2003:260). Volgens hom is selfbejammering 'n siek skouspel (Miles, 2003:266).

Hierdie woorde van Smerski oor boetedoening verwys eerstens na die konteks van die Waarheids- en Versoeningskommissie (WVK) wat ten tyde van die verskyning van die roman veral aktueel was. Smerski se gesukkel om die waarheid stelselmatig te onthul, maak van die boek een groot stuk konfessie - 'n konfessie wat nie maklik kom nie. Die hele verloop van die gebeure weerspreek eintlik Smerski se smalende woorde oor bieg. Smerski word algaande gedwing om al hoe meer omtrent homself en sy dade te openbaar en te bieg. 
Dinge wat die diepste weggesteek word, is juis die moeilikste om na vore te kom. Smerski word in hierdie biegproses deur die vrou wat hy liefkry, Isabel, gelei. Soos die verskillende lae van die skildery van Donna Isabel moeisaam afgeskil word om die manlike figuur na vore te bring, bieg Smerski stelselmatig meer en meer. Die vrou help in 'n soort psigoanalitiese "praatkuur". Dit is vir hom 'n genesende praatkuur. Smerski kan sodoende uit die niemandsland van die buiteveld waarin hy so lank was, teen die einde na sy vaderland terugkeer - grootliks bevry van sy skuld. Hierin is die vrouefiguur sy gids wat hom stelselmatig lei.

\section{Slotsom}

Verskillende terugkerende kodes word in die roman, Die buiteveld, van John Miles gevind. Dit dien om skuld en boetedoening uit te beeld en skuld word sodoende die belangrike en oorkoepelende Leitmotiv van die roman. Selfs om na die "buiteveld" te vlug, kan nie aandadigheid en skuld vernietig nie. Skuld word op verskillende maniere vasgelê en verewig, naamlik deur herhalende motiewe soos herhalende verwysings na skilderye van die portret- en oorlogskilder Goya, foto's, kameras, littekens en 'n gevaarlike knipmes. Hierdeur word skuld ' $n$ oorweldigende en immerteenwoordige tema. Die leser maak hierdie proses mee en word, soos Barthes sê, nie 'n verbruiker (consumer) van die teks nie, maar self ook 'n vervaardiger (producer) daarvan (Barthes, 1974:4).

\section{Geraadpleegde bronne}

ABRAHAMS, M.H. 1981. A glossary of literary terms. New York: Holt, Rinehart \& Winston.

BARTHES, R. 1974. S/Z. Trans. by R. Miller. New York: The Noonday Press.

BURGER, W. 2003. Miles-roman belangrik - maar problematies. Rapport: 16, 2 Nov.

CARR-GOMM, S. 2005. Francisco Goya. London: Grange Books.

CLOETE, T.T., red. 1992. Literêre terme en teorieë. Pretoria: HAUM-Literêr.

FORSTER, E.M. 1927. Aspects of the novel. London: Arnold.

FOWLER, R. 1973. A dictionary of modern critical terms. London: Routledge \& Kegan Paul.

GROVÉ, A.P. 1963. Letterkundige sakwoordeboek vir Afrikaans. Kaapstad: Nasou.

HOWARD, M. 2003. Goya. London: Cartwell Books.

LINDELL, R. 1967. A teatrise on the novel. London: Johanathan Cape.

MILES, J. 2003. Die buiteveld. Kaapstad: Human \& Rousseau.

PAKENDORF, G. 2003. Steeds in die grensgebied: tog laat Miles vrae oor skuld en boetedoening onbeantwoord. Die Burger: 15, 15 Des.

RIMMON-KENAN, S. 1983. Narrative fiction: contemporary poetics. London: Routledge. 
ROOS, H. 2004. John Miles terug uit die buiteveld. Tydskrif vir letterkunde, 41(1):138-152.

SELDEN, R. \& WIDDOWSON, P. 1993. A reader's guide to contemporary literary theory. New York: Harvester Wheatsheaf.

SHIPLEY, J.T. 1968. Dictionary of world literature. Totowa: Littlefield \& Adams.

VENTER, L.S. Steeds 'n betrokke skrywer. Beeld: 11, 8 Des.

WELLEK, R. \& WARREN, A. 1973. Theory of literature. New rev. ed. New York: Harvest Books.

\section{Kernbegrippe:}

\section{Goya}

herhalende motiewe in 'n roman

Miles, John

skuldmotief

\section{Key concepts:}

\section{Goya}

guilt motive

Miles, John

recurring elements in a novel 